\title{
Effects of Core and/or Peripheral Protonation of meso-Tetra(2-, 3-, and 4-pyridyl)Porphyrin and meso-Tetra(3-methylpyridyl)Porphyrin on Their UV-vis Spectra
}

\author{
Saeed Zakavi, ${ }^{1}$ Hajar Rahiminezhad, ${ }^{2}$ Aida Ghanbelanie Mojarrad, \\ Tahereh Mokary Yazdeli, ${ }^{1}$ and Robabeh Alizadeh $^{2}$ \\ ${ }^{1}$ Department of Chemistry, Institute for Advanced Studies in Basic Sciences, Zanjan 45137-66731, Iran \\ ${ }^{2}$ School of Chemistry, Damghan University, Damghan 36716-41167, Iran
}

Correspondence should be addressed to Saeed Zakavi; zakavi@iasbs.ac.ir

Received 11 June 2012; Revised 19 July 2012; Accepted 20 July 2012

Academic Editor: Christophe Dujardin

Copyright (C) 2013 Saeed Zakavi et al. This is an open access article distributed under the Creative Commons Attribution License, which permits unrestricted use, distribution, and reproduction in any medium, provided the original work is properly cited.

\begin{abstract}
Core and/or peripheral protonation of meso-tetra(pyridyl)porphyrins, $\mathrm{H}_{2}$ (py)P, with weak and strong acids have been studied by UV-vis spectroscopy. The results support the proposal that the position of the Soret as well as the Q $(0,0)$ bands of the dications is influenced by $\pi$ donation from the meso substituents to the porphyrin core. The red shift of the $\mathrm{Q}(0,0)$ band of $\mathrm{H}_{2} \mathrm{t}(\mathrm{py}) \mathrm{P}$ dications with 2-, 3-, and 4-pyridyl substituents does not correlate with the order of $\pi$ electron donor ability of the meso groups. The decreased electron donation from the central nitrogen atoms to the acids on going from 3-pyridyl group to 4- and 2-pyridyl ones has been used to explain this observation. In spite of the negative effect of $\mathrm{N}$-methylation of pyridyl substituents on the basicity of the central nitrogen atoms of meso-tetra(3-methylpyridyl)porphyrin, $\mathrm{H}_{2} \mathrm{t}(3-\mathrm{Mepy}) \mathrm{P}$, protonation of $\mathrm{H}_{2} \mathrm{t}(3-\mathrm{Mepy}) \mathrm{P}$ occurs with weak and strong acids. The blue shift of the $\mathrm{Q}(0,0)$ bands upon protonation of $\mathrm{H}_{2} \mathrm{t}(3-\mathrm{Mepy}) \mathrm{P}$ with weak and strong acids clearly shows the importance of resonance interactions between the $\pi$-systems of porphyrin and the aryl substituents on the position of the band.
\end{abstract}

\section{Introduction}

Core protonation of porphyrins with weak and strong Lewis and protic acids has been the subject of many studies since the late 1970s [1-10]. X-ray crystallographic studies on many porphyrin dications have shown a distorted (mainly saddled) conformation of the aromatic macrocycle [1,4-6]. In other words, protonation of central nitrogen atoms of porphyrin may be used to induce nonplanarity in porphyrins. Several properties of porphyrins and metalloporphyrins including their redox potentials, basicity, and axial ligand binding affinity which can influence the biological function of porphyrin cofactors in proteins are known to be modified by nonplanar distortions of the aromatic macrocycle. Host-guest interactions and the enantioselectivity of catalytic epoxidation can be also tuned by the out-of-plane deformations [11]. On the other hand, nonplanar porphyrins and the influence of the out-of-plane deformations of the macrocycle on their UVvis spectroscopy have been of great interest to both experimental and computational chemists $[6-8,11,12]$. Indeed, the spectral changes caused by the out-of-plane deformation of porphyrins might be used to probe the structures of hemes, chlorophylls, and related photosynthetic pigments, and other tetrapyrrole cofactors in proteins [11]. While in free base porphyrins, the meso-aryl groups are nearly perpendicular to the porphyrin mean plane $[2,13]$, the dihedral angles between the aryl substituents at meso-positions, and the porphyrin mean plane substantially decrease upon protonation of porphyrin core, leading to enhanced resonance interactions between the $\pi$-system of porphyrin and that of the aryl substituents $[2,6,7]$ and consequently, the difference between the electron-withdrawing/donating ability of various meso-substituents is more pronounced compared to the case of the free base porphyrins. The dependence 
of the position of the $\mathrm{Q}(0,0)$ bands of the dications of a series of para-substituted meso-tetraarylporphyrins on the electronic effects of meso-substituents has been studied in our previous work [8]. Also, the position of the $\mathrm{Q}(0,0)$ band of the dication of a series of meso- and/or $\beta$ substituted porphyrins with $\mathrm{CF}_{3} \mathrm{COOH}$ was found to correlate with the electronwithdrawing or electron-donating ability of the groups at the periphery of the porphyrin macrocycle [14].

X-ray crystallography confirmed the formation of a hexaprotonated salt upon protonation of meso-tetra(4pyridyl)porphyrin with $\mathrm{HCl}$ in water [1]. In the present work, core and full protonation of meso-tetra(2-, 3-, and 4-pyridyl)porphyrins, $\mathrm{H}_{2} \mathrm{t}(\mathrm{py}) \mathrm{P}$, and diprotonation of mesotetra(3-methylpyridyl)porphyrin, $\mathrm{H}_{2} \mathrm{t}$ (3-Mepy)P (Figure 1) with different acids are reported. The influence of electronic effects of the meso-substituents on the amount and direction of the shifts of the Soret and the $\mathrm{Q}(0,0)$ bands has been studied and compared. The results clearly demonstrate the importance of protonation or N-methylation (in the case of $\mathrm{H}_{2} \mathrm{t}(3-\mathrm{Mepy}) \mathrm{P}$ ) of the pyridyl groups on the shifts of the Soret and $\mathrm{Q}(0,0)$ bands of the core protonated $\mathrm{H}_{2} \mathrm{t}(\mathrm{py}) \mathrm{P}$.

\section{Experimental}

2.1. Instrumental. ${ }^{1} \mathrm{H}$ NMR spectra were obtained on a Bruker Avance DPX-400 MHz spectrometer. The absorption spectra were recorded on a Pharmacia Biotech Ultrospec 4000 UV-Vis spectrophotometer.

\subsection{Preparation of the Free Base Porphyrins. meso-tetra} (pyridyl)porphyrins were synthesized and purified according to the literature methods [15-17] with some modifications, explained in our recent work [18]. $\mathrm{H}_{2} \mathrm{t}$ (3-Mepy)P was prepared and purified using the procedure described by Pasternack et al. [16, 19].

2.3. Full Protonation of the Porphyrins. A sample of $\mathrm{H}_{2} \mathrm{t}(\mathrm{py}) \mathrm{P}$ was dissolved in $20 \mathrm{~mL}$ of dichloromethane and $5 \mathrm{~mL}$ of concentrated strong acid (aqueous solution of $\mathrm{HNO}_{3}, \mathrm{HCl}$, $\mathrm{HClO}_{4}, \mathrm{H}_{2} \mathrm{SO}_{4}$ or $\mathrm{HNO}_{3}$ with $\mathrm{pH}$ adjusted to zero) acid was added. The mixture was stirred until the disappearnace of the Soret band due to the free base porphyrin in the UV-vis spectra of the organic phase. As we have shown previously, due to the high dielectric constant of water, there is no detectable difference between the UV-vis spectrum of the dications of a given $\mathrm{H}_{2} \mathrm{t}(\mathrm{py}) \mathrm{P}$ with different acids in water [20]. The formation of hexaprotonated species under this $\mathrm{pH}$ condition was previously confirmed by $\mathrm{X}$ ray crystallographic studies [1]. It is noteworthy that the hexaprotonated species $\mathrm{H}_{2} \mathrm{t}(\mathrm{py}) \mathrm{P}$ is completely insoluble in dichloromethane and therefore it cannot be extracted with dichloromethane from the acidic $(\mathrm{pH}=0)$ aqueous phase [18].

2.4. Preparation of the Diprotonated Species of $\mathrm{H}_{2} t(p y) P$ and $\mathrm{H}_{2} t$ (3-Mepy)P. The pyridyl groups of $\mathrm{H}_{2} \mathrm{t}$ (py)P are less basic than the pyrrolenine nitrogen atoms; it has been indicated that upon protonation of pyrrolenine nitrogen atoms of meso$\operatorname{di}\left(2-, 3-\right.$, or 4 -pyridyl)porphyrins $\left(\approx 10^{-5}\right.$ to $\left.10^{-4} \mathrm{M}\right)$ with $\mathrm{H}_{2} \mathrm{SO}_{4}$ in ethanol $\left(\approx 10^{-5}\right.$ to $\left.10^{-3} \mathrm{M}\right)$, the pyridyl groups remain intact and only protonation of the porphyrin core occurs [21]. It should be noted that although Aronoff's spectrophotometric titration of $\mathrm{H}_{2}$ tpp with $\mathrm{CF}_{3} \mathrm{COOH}$ in nitrobenzene has given an intermediate spectrum attributed to a monoprotonated moiety, $\left[\mathrm{H}_{3} \mathrm{TPP}\right]^{+}$, there has been no evidence for a monoprotonated intermediate between the free base and the diprotonated porphyrin in chloroform and dichloromethane $[14,19,20]$. Accordingly, addition of 2:1 molar ratio of acid (including $\mathrm{HNO}_{3}, \mathrm{HCl}, \mathrm{HClO}_{4}$, $\mathrm{H}_{2} \mathrm{SO}_{4}, \mathrm{HNO}_{3}, \mathrm{H}_{2} \mathrm{C}_{2} \mathrm{O}_{4}$, and $\mathrm{CF}_{3} \mathrm{COOH}$ ) to $\mathrm{H}_{2} \mathrm{t}(\mathrm{py}) \mathrm{P}$ in dichloromethane gives the diprotonated porphyrins. Due to the presence of an equilibrium between the diprotonated species and the free base porphyrins (especially in the case of weak acid, i.e., $\mathrm{CH}_{3} \mathrm{COOH}$ ), under high dilution conditions which is usually used to prepare the UV-vis spectra, the Soret band of the free base porphyrin is also observed in addition to that of the diprotonated porphyrin. In this condition, an excess amount of acid should be used for completeness of the reaction $[8,20]$. Figure 2 demonstrates the UV-vis spectrum of a solution of $\mathrm{H}_{2} \mathrm{t}(3-\mathrm{py}) \mathrm{P}\left(\sim 10^{-5} \mathrm{M}\right)$ in dichloromethane after the addition of concentrated perchloric acid in $1: 1$ molar ratio. Here, the absorption bands due to the free base porphyrin $\left(\lambda_{\max }=418 \mathrm{~nm}\right)$ and the corresponding dication, $\left[\mathrm{H}_{4} \mathrm{t}(3-\mathrm{py}) \mathrm{P}\right]\left(\mathrm{ClO}_{4}\right)_{2}\left(\lambda_{\max }=453 \mathrm{~nm}\right)$, are observed.

$\mathrm{H}_{2} \mathrm{t}(3-$ Mepy) $\mathrm{P}$ is insoluble in dichloromethane and consequently the reactions with acids were performed in methanol. In the case of $\mathrm{H}_{2} \mathrm{t}$ (3-Mepy) $\mathrm{P}$, due to the decreased basicity of the pyrrolenine nitrogen atoms caused by the methylation of pyridyl groups, excess amounts of acid (beyond 2:1 molar ratio of acid to porphyrin) should be used to ensure the completion of the reaction (Figure 3). However, the employment of excess amounts of acid led to no detectable change in the position of the Soret and $\mathrm{Q}(0,0)$ bands.

\section{Results and Discussion}

3.1. Shift of the Soret and $Q(0,0)$ Bands of $H_{2} t(p y) P$ in Reaction with Strong Acids. Hexaprotonation of $\mathrm{H}_{2} \mathrm{t}(2-, 3-$ , or 4-py)P with $\mathrm{HCl}$ in water $(\mathrm{pH}=0)$ leads to red shift of the Soret bands and the blue shift of the $\mathrm{Q}(0,0)$ bands (Table 1). Diprotonation of these porphyrins with $\mathrm{HCl}$ (Table 2 ), on the other hand, causes the shifts of the bands to longer wavelengths. Also, the shifts of the Soret bands are significantly larger than those observed in hexaprotonation of the porphyrins.

There are several factors which may influence the position of the absorption bands of porphyrin diacids including the out-of-plane deformation of porphyrin core, shift of electron density from the pyrrolenine nitrogens to the acids, and enhanced coplanarity of the meso aryl substituents and the porphyrin mean plane $[2,4,8,14,20]$. According to the four orbital model of porphyrin spectra, the electron densities of the $\mathrm{a}_{1 \mathrm{u}}$ orbitals are on the $\alpha$ and $\beta$ carbon atoms and those of the $\mathrm{a}_{2 \mathrm{u}}$ orbitals are largest on the meso positions and central nitrogen atoms [22]. In other words, the meso carbon atoms 

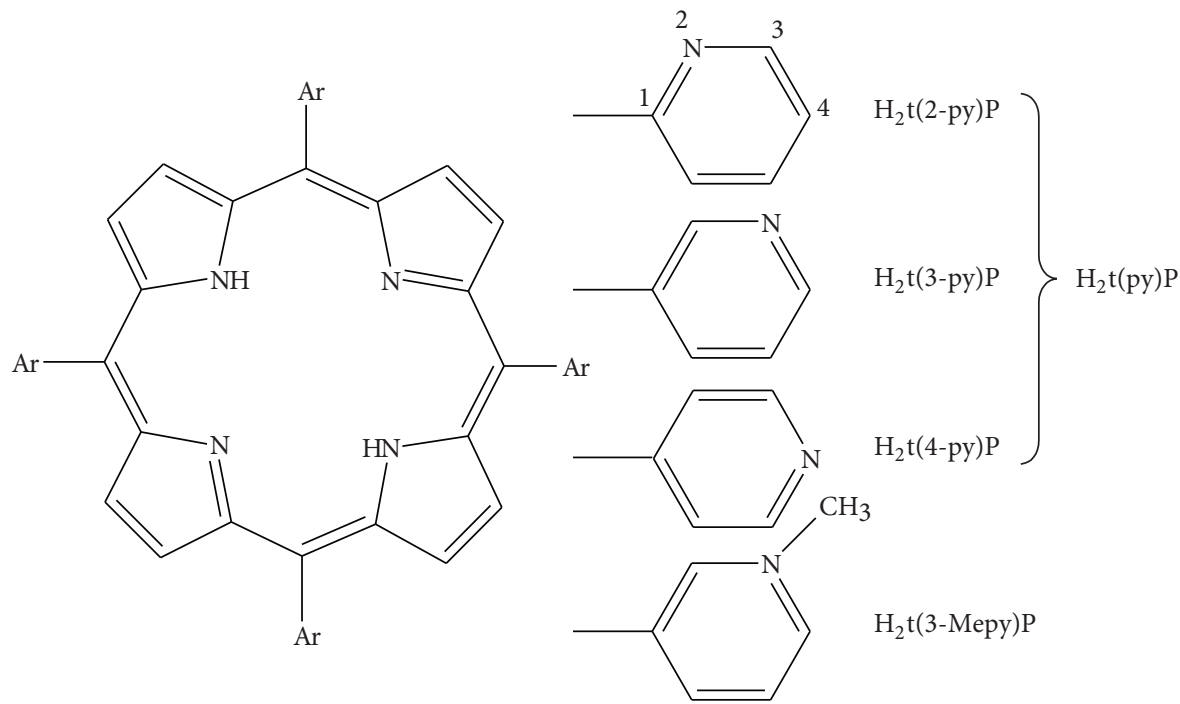

FIGURE 1: The porphyrins used in this study.

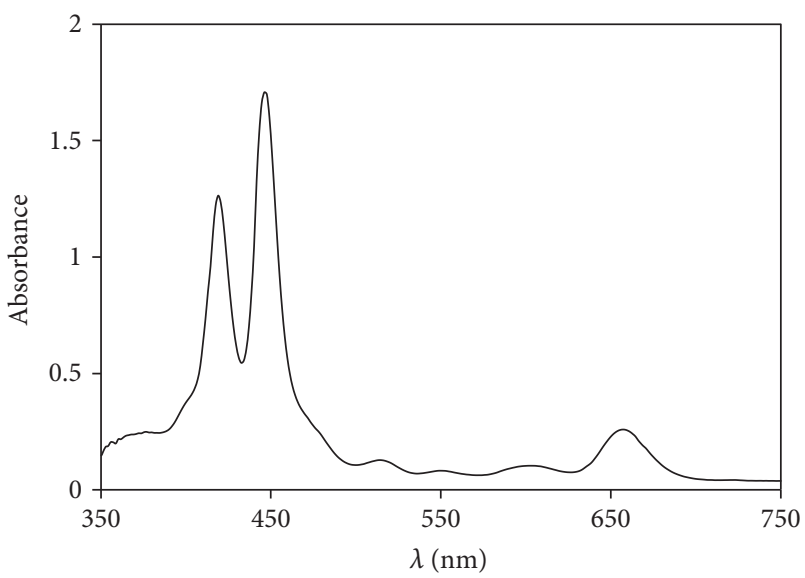

Figure 2: The free base $\mathrm{H}_{2} \mathrm{t}(3-\mathrm{py}) \mathrm{P}\left(\lambda_{\max }=418 \mathrm{~nm}\right)$ in equilibrium with $\left[\mathrm{H}_{4} \mathrm{t}(3-\mathrm{py}) \mathrm{P}\right]\left(\mathrm{ClO}_{4}\right)_{2}\left(\lambda_{\max }=453 \mathrm{~nm}\right)$ in dichloromethane (see the text).

lie on the nodal planes of the $\mathrm{a}_{1 \mathrm{u}}$ orbitals and therefore the $\mathrm{a}_{2 \mathrm{u}}$ to $\mathrm{e}_{g}$ transitions of the dications, that is, the $\mathrm{Q}$ bands are expected to be strongly influenced by the change of $\pi$-donor ability of the meso groups. The red shift of the $\mathrm{Q}(0,0)$ bands of diprotonated meso-tetra(pyridyl)porphyrins compared to the blue shifts of the corresponding bands of the hexaprotonated species may be attributed to the weaker $\pi$ donor ability of the protonated pyridyl substituents with respect to the nonprotonated ones. The observed shift of the Soret band of porphyrins upon protonation with different acids is primarily due to the saddling of porphyrin core $[8,12,14]$, but as we have previously suggested [8], a through space (i.e., without the necessity of the presence of a chemical bond) interaction between the HOMOs of meso aryl groups and the porphyrin $\pi$ system (Figure 4) may be considered causing the red shift of the Soret band [8].

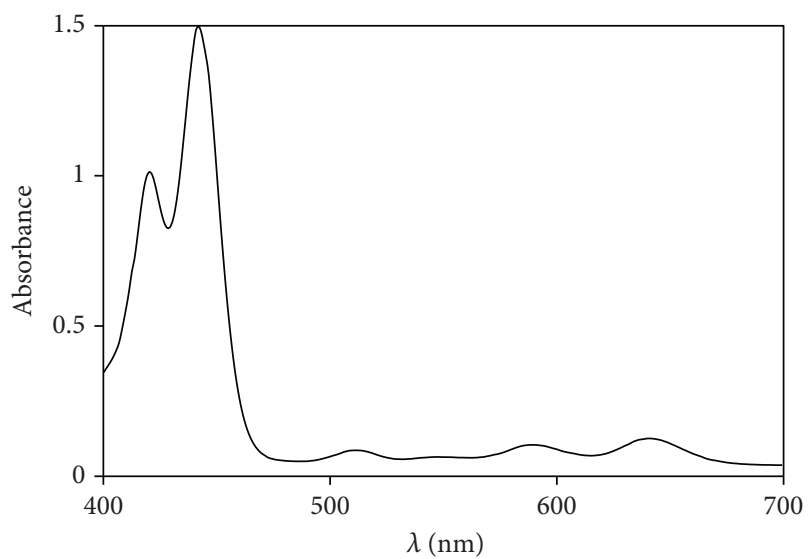

Figure 3: The free base $\mathrm{H}_{2} \mathrm{t}$ (3-Mepy)P $\left(\lambda_{\max }=419 \mathrm{~nm}\right)$ in equilibrium with $\left[\mathrm{H}_{4} \mathrm{t}(3-\mathrm{Mepy}) \mathrm{P}\right](\mathrm{Cl})_{2}\left(\lambda_{\max }=433 \mathrm{~nm}\right)$, in methanol; $1: 2$ molar ratio of $\mathrm{H}_{2} \mathrm{t}(3-\mathrm{Mepy}) \mathrm{P}$ to $\mathrm{HCl}$ was used.

It is noteworthy that different bulk of the substituents at meso positions is an important factor influencing the extent of saddling of porphyrin core, the dihedral angle between the aryl groups and the porphyrin mean plane, and consequently the shift of the absorption bands [4]. However, in the absence of substitution of the ortho positions of meso aryl groups with bulky susbstituents such as $-\mathrm{CH}_{3}$ and $-\mathrm{Cl}$ [4], the aryl groups have approximately the same steric bulk.

The observed red shift of the long wavelength band of the dications of $\mathrm{H}_{2} \mathrm{t}(\mathrm{py}) \mathrm{P}$ with $\mathrm{HCl}$ (Table 2) decreases in the order $\left[\mathrm{H}_{4} \mathrm{t}(2-\mathrm{py}) \mathrm{p}\right](\mathrm{Cl})_{2}>\left[\mathrm{H}_{4} \mathrm{t}(4-\mathrm{py}) \mathrm{p}\right](\mathrm{Cl})_{2}>>$ $\left[\mathrm{H}_{4} \mathrm{t}(3-\mathrm{py}) \mathrm{P}\right](\mathrm{Cl})_{2}$. Meot-Ner et al. show that the basicity of the pyrrolenine nitrogens of porphyrin as well as the UV-vis spectral shifts upon the core protonation of a series of porphyrins with weak or strong electron-donating groups at the meso positions correlate to predominantly resonance type interactions between the aryl groups and 
TABLE 1: UV-vis spectral data for hexaprotonation of $\mathrm{H}_{2} \mathrm{t}(\mathrm{py}) \mathrm{p}$ with $\mathrm{HCl}$ in water $(\mathrm{pH}=0)^{\mathrm{a}}$.

\begin{tabular}{lcc}
\hline Porphyrins and the dications & $\begin{array}{c}\text { Soret band } \\
(\lambda / \mathrm{nm})\end{array}$ & $\begin{array}{c}\mathrm{Q}(0,0) \text { band } \\
(\lambda / \mathrm{nm})\end{array}$ \\
\hline $\mathrm{H}_{2} \mathrm{t}(2-\mathrm{py}) \mathrm{p}$ & 417.0 & 642.0 \\
{$\left[\mathrm{H}_{6} \mathrm{t}(2-\mathrm{py}) \mathrm{p}\right](\mathrm{Cl})_{6}$} & 436.3 & 636.2 \\
$\Delta \nu\left(\mathrm{cm}^{-1}\right)^{\mathrm{b}}$ & -106.0 & 142.0 \\
$\mathrm{H}_{2} \mathrm{t}(3-\mathrm{py}) \mathrm{p}$ & 418.0 & 646.4 \\
{$\left[\mathrm{H}_{6} \mathrm{t}(3-\mathrm{py}) \mathrm{p}\right](\mathrm{Cl})_{6}$} & 435.0 & 636.0 \\
$\Delta \nu\left(\mathrm{cm}^{-1}\right)$ & -935.0 & 253.0 \\
$\mathrm{H}_{2} \mathrm{t}(4-\mathrm{py}) \mathrm{p}$ & 416.0 & 643.0 \\
{$\left[\mathrm{H}_{6} \mathrm{t}(4-\mathrm{py}) \mathrm{p}\right](\mathrm{Cl})_{6}$} & 440.8 & 636.2 \\
$\Delta v\left(\mathrm{~cm}^{-1}\right)$ & -1352 & 166.0 \\
\hline
\end{tabular}

${ }^{a}$ See Section 2.3 for details. The hexaprotonated species are completely insoluble in dichloromethane. ${ }^{\mathrm{b}} \Delta v\left(\mathrm{~cm}^{-1}\right)=10^{7}\left(1 / \lambda_{2}-1 / \lambda_{1}\right)$, relative to the corresponding free base porphyrin.

TABLE 2: UV-vis spectral data for the interaction of $\mathrm{H}_{2} \mathrm{t}(\mathrm{py}) \mathrm{P}$ with $\mathrm{HCl}$ in $\mathrm{CH}_{2} \mathrm{Cl}_{2}{ }^{\mathrm{a}}$.

\begin{tabular}{lcc}
\hline Porphyrins and the dications & $\begin{array}{c}\text { Soret band } \\
(\lambda / \mathrm{nm})\end{array}$ & $\begin{array}{c}\mathrm{Q}(0,0) \text { band } \\
(\lambda / \mathrm{nm})\end{array}$ \\
\hline $\mathrm{H}_{2} \mathrm{t}(2-$ py $) \mathrm{P}$ & 417.0 & 642.0 \\
{$\left[\mathrm{H}_{4} \mathrm{t}(2-\mathrm{py}) \mathrm{P}\right](\mathrm{Cl})_{2}$} & 471.3 & 662.2 \\
$\Delta v\left(\mathrm{~cm}^{-1}\right)$ & -2762.9 & -475.2 \\
$\mathrm{H}_{2} \mathrm{t}(3-$ py $) \mathrm{P}$ & 418.0 & 646.4 \\
{$\left[\mathrm{H}_{4} \mathrm{t}(3-\mathrm{py}) P\right](\mathrm{Cl})_{2}$} & 451.0 & 647.5 \\
$\Delta v\left(\mathrm{~cm}^{-1}\right)$ & -1750.9 & -26.2 \\
$\mathrm{H}_{2} \mathrm{t}(4-\mathrm{py}) \mathrm{P}$ & 416.0 & 643.0 \\
{$\left[\mathrm{H}_{4} \mathrm{t}(4-\right.$ py $\left.) P\right](\mathrm{Cl})_{2}$} & 470.2 & 661.0 \\
$\Delta v\left(\mathrm{~cm}^{-1}\right)$ & -2770.9 & -425.3 \\
\hline
\end{tabular}

${ }^{a}$ See Section 2.3 for details.

porphyrin aromatic system [2]. In other words, raising of the electron density on the $\mathrm{a}_{2 \mathrm{u}}$ orbital by electron-donating substituents causes the observed red shift of the $\mathrm{Q}(0,0)$ band of strongly electron-donating porphyrins such as mesotetra(4-hydroxyphenyl)porphyrin. The relative success of the electrophilic substitution reactions of pyridine correlates with the electron density distribution at the various positions of the pyridine ring; electrophilic attack at pyridine occurs at the meta positions relative to the heteroatom [23, 24]; according to the resonance forms of pyridine, a positive charge spreads on the aromatic ring which decreases as meta $\leq$ para $<$ ortho [23]. In the case of $\left[\mathrm{H}_{4} \mathrm{t}(2-\mathrm{py}) \mathrm{P}\right](\mathrm{Cl})_{2},\left[\mathrm{H}_{4} \mathrm{t}(4-\mathrm{py}) \mathrm{P}\right](\mathrm{Cl})_{2}$, and $\left[\mathrm{H}_{4} \mathrm{t}(3-\mathrm{py}) \mathrm{P}\right](\mathrm{Cl})_{2}$, the meso position of the macrocycle is attached to the ortho, para, and meta positions of the pyridyl group, respectively (Figure 5).

Accordingly, the pyridyl groups of $\left[\mathrm{H}_{4} \mathrm{t}(3-\mathrm{py}) \mathrm{P}\right](\mathrm{Cl})_{2}$ are expected to be better electron-donating groups to the $\mathrm{a}_{2 \mathrm{u}}$ orbital in comparison with those of $\left[\mathrm{H}_{4} \mathrm{t}(4-\mathrm{py}) \mathrm{P}\right](\mathrm{Cl})_{2}$ and $\left[\mathrm{H}_{4} \mathrm{t}(2\right.$-py) $\mathrm{P}](\mathrm{Cl})_{2}$. On the basis of the above discussion, the observed red shift of the $\mathrm{Q}(0,0)$ bands of these porphyrins does not correlate with the order of electron donor ability of the pyridyl substituents. Also, the same trend was observed for the dications of $\mathrm{H}_{2} \mathrm{t}$ (py)P with oxalic, nitric, and sulfuric

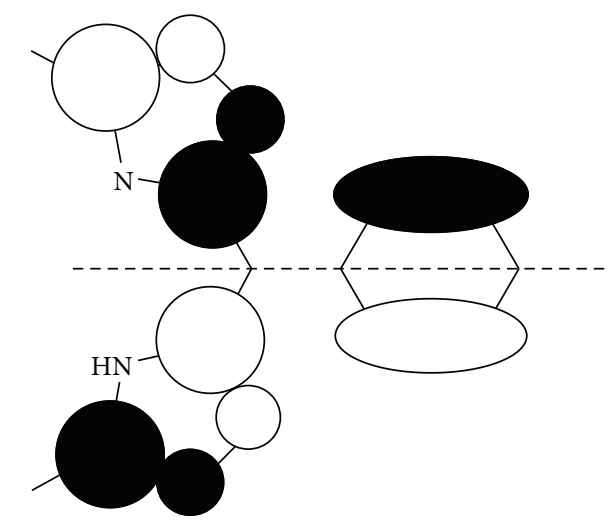

Figure 4: A possible through space interaction between the porphyrin $\mathrm{a}_{1 \mathrm{u}}$ orbital and one of the $\mathrm{e}_{1 \mathrm{~g}}$ orbitals of the aryl group [8].

acid (see Tables S1-S3) (see supplementary materials available online at http://dx.doi.org/10.1155/2013/713745).

Indeed, the order is contrary to that one would predict from the electronic properties of the meso groups. In a previous work [8], we have shown that while the saddling of porphyrin core and the enhanced coplanarity of the meso aryls and porphyrin aromatic system lead to the red shift of the $\mathrm{Q}(0,0)$ band $[1,2,12]$, the shift of electron density from the central nitrogen atoms (donors) to the acids (acceptors) causes the blue shift of the $\mathrm{Q}(0,0)$ band. The presence of strong electron-donating groups such as 4-methoxyphenyl at meso positions was shown to compensate the blue shift caused by the donor-acceptor interactions and result in the large red shift of the band upon protonation of meso-tetra(4methoxyphenyl)porphyrin with $\mathrm{CF}_{3} \mathrm{COOH}$ [8]. On the other hand, the large blue shift of the $\mathrm{Q}(0,0)$ band of meso-tetra $(n$ propyl)porphyrin dications is consistent with the lack of proper $\pi$ electron-donating groups at the meso positions.

In comparison of the three porphyrins with pyridyl substituents, the larger blue shift of the band in the case of $\left[\mathrm{H}_{4} \mathrm{t}(3-\mathrm{py}) \mathrm{p}\right](\mathrm{Cl})_{2}$, caused by the better electron donation from the central nitrogen atoms to the acid molecule, seems to be responsible for the observed order of shift of the $Q(0,0)$ bands.

According to data of Tables 1, 2, 3, and 4 and Table $\mathrm{S} 1-\mathrm{S} 3$, the larger shift of the Soret band for a given $\mathrm{H}_{2} \mathrm{t}(\mathrm{py}) \mathrm{P}$ occurs in the protonation with $\mathrm{HCl}$. The size and hydrogen bond acceptor ability of the counteranion of porphyrin dications play an important role in the extent of saddling of porphyrin core and stability of the adduct $[1,6,8,9,20]$. It has been shown that in a series of diprotonated mesotetra(phenyl)porphyrin, $\left[\mathrm{H}_{4} \mathrm{TPP}\right](\mathrm{X})_{2}(\mathrm{X}=\mathrm{F}, \mathrm{Cl}, \mathrm{Br}, \mathrm{I})$, the degree of saddling of porphyrin core increases with increasing size of the halide. It was suggested that the necessity to optimize the hydrogen bond interactions between the halides and the dication is an additional factor in determining the actual degree of saddling [6]. Accordingly, the larger size of $\mathrm{Cl}^{-}$relative to the oxygen residues of $\mathrm{ClO}_{4}{ }^{-}$and $\mathrm{CF}_{3} \mathrm{COO}^{-}$as well as the stronger hydrogen bond of $\mathrm{Cl}-\mathrm{H}$ than that of $\mathrm{O}-\mathrm{H}$ may explain the increased red shift of the Soret band for the dications with $\mathrm{HCl}$. 


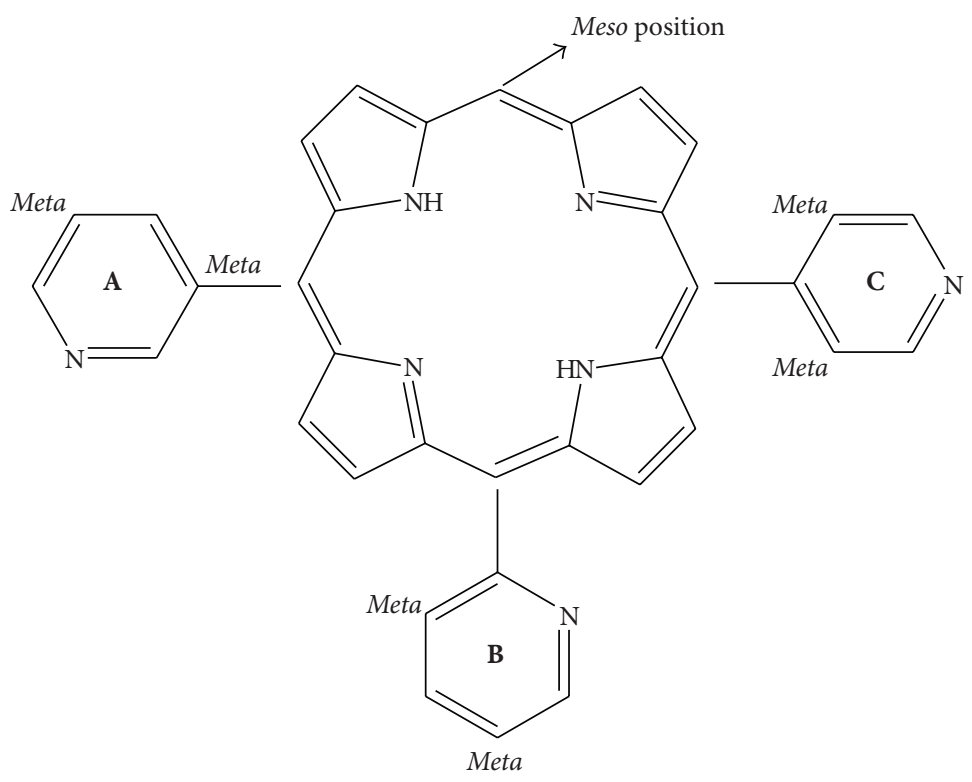

Figure 5: The meta positions of pyridyl substituents relative to the meso carbon atoms of $\mathrm{H}_{2} \mathrm{t}(3-\mathrm{py}) \mathrm{P}(\mathbf{A}), \mathrm{H}_{2} \mathrm{t}(2-\mathrm{py}) \mathrm{P}(\mathbf{B})$, and $\mathrm{H}_{2} \mathrm{t}(4-\mathrm{py}) \mathrm{P}$ (C).

TABLE 3: UV-vis spectral data for the diprotonated $\mathrm{H}_{2} \mathrm{t}(\mathrm{py}) \mathrm{P}$ with $\mathrm{CF}_{3} \mathrm{COOH}$ in $\mathrm{CH}_{2} \mathrm{Cl}_{2}{ }^{\mathrm{a}}$.

\begin{tabular}{lcc}
\hline Porphyrins and the dications & $\begin{array}{c}\text { Soret band } \\
(\lambda / \mathrm{nm})\end{array}$ & $\begin{array}{c}\mathrm{Q}(0,0) \text { band } \\
(\lambda / \mathrm{nm})\end{array}$ \\
\hline $\mathrm{H}_{2} \mathrm{t}(2-$ py $) \mathrm{P}$ & 417.0 & 642.0 \\
{$\left[\mathrm{H}_{4} \mathrm{t}(2-\right.$ py $\left.) \mathrm{P}\right]\left(\mathrm{CF}_{3} \mathrm{COO}\right)_{2}$} & 443.0 & 647.0 \\
$\Delta v\left(\mathrm{~cm}^{-1}\right)$ & -1407.0 & -121.0 \\
$\mathrm{H}_{2} \mathrm{t}(3-$ py $) \mathrm{P}$ & 418.0 & 646.0 \\
{$\left[\mathrm{H}_{4} \mathrm{t}(3-\mathrm{py}) \mathrm{P}\right]\left(\mathrm{CF}_{3} \mathrm{COO}\right)_{2}$} & 442.0 & 645.0 \\
$\Delta v\left(\mathrm{~cm}^{-1}\right)$ & -1299.0 & 33.0 \\
$\mathrm{H}_{2} \mathrm{t}(4-$ py $) \mathrm{P}$ & 416.0 & 643.0 \\
{$\left[\mathrm{H}_{4} \mathrm{t}(4-\right.$ py $\left.) \mathrm{P}\right]\left(\mathrm{CF}_{3} \mathrm{COO}\right)_{2}$} & 442.0 & 638.0 \\
$\Delta v\left(\mathrm{~cm}^{-1}\right)$ & -1409.0 & 112.0 \\
\hline
\end{tabular}

${ }^{\mathrm{a}}$ See the footnotes of Table 2 .

3.2. Interaction of $\mathrm{H}_{2} t(p y) P$ with $\mathrm{CH}_{3} \mathrm{COOH}$ as a Weak Acid. We have reported the interaction of meso-tetra(aryl)and meso-tetra(alkyl)porphyrins with weak carboxylic acids in 2007 [8]. In spite of the lower basicity of meso-tetra (pyridyl)porphyrins with respect to meso-tetra(phenyl) porphyrin $[2,21]$, interaction of the former with $\mathrm{CH}_{3} \mathrm{COOH}$ is evident from the shift of the absorption bands in the UV-vis spectra (Table 5).

3.3. Interaction of $\mathrm{H}_{2} t(3-\mathrm{Mepy}) \mathrm{P}$ with Weak and Strong Acids. With regard to the significant influence of the meso substituents on the basicity of meso-tetra(aryl)porphyrins $[2,21]$, methylation of the pyridyl substituents of $\mathrm{H}_{2} \mathrm{t}(3-\mathrm{py}) \mathrm{P}$ which creates a positive charge over the pyridyl moiety is expected to decrease the basicity of $\mathrm{H}_{2} \mathrm{t}$ (3-Mepy) $\mathrm{P}$ compared to the nonmethylated porphyrin. As in the case of $\mathrm{H}_{2} \mathrm{t}(3-\mathrm{py}) \mathrm{P}$, upon the addition of weak and strong acids to the solution
TABLE 4: UV-vis spectral data for the dications of $\mathrm{H}_{2} \mathrm{t}($ py)P with $\mathrm{HClO}_{4}$ in $\mathrm{CH}_{2} \mathrm{Cl}_{2}{ }^{\mathrm{a}}$.

\begin{tabular}{lcc}
\hline Porphyrins and the dications & $\begin{array}{c}\text { Soret band } \\
(\lambda / \mathrm{nm})\end{array}$ & $\begin{array}{c}\mathrm{Q}(0,0) \text { band } \\
(\lambda / \mathrm{nm})\end{array}$ \\
\hline $\mathrm{H}_{2} \mathrm{t}(2$-py $) \mathrm{P}$ & 417.0 & 642.0 \\
{$\left[\mathrm{H}_{4} \mathrm{t}(2\right.$-py)P $]\left(\mathrm{ClO}_{4}\right)_{2}$} & 471.3 & 663.3 \\
$\Delta v\left(\mathrm{~cm}^{-1}\right)$ & -2762.9 & -500.2 \\
$\mathrm{H}_{2} \mathrm{t}(3-\mathrm{py}) \mathrm{P}$ & 418.0 & 646.4 \\
{$\left[\mathrm{H}_{4} \mathrm{t}(3-\mathrm{py}) \mathrm{P}\right]\left(\mathrm{ClO}_{4}\right)_{2}$} & 458.9 & 653.1 \\
$\Delta v\left(\mathrm{~cm}^{-1}\right)$ & -2132.2 & -158.7 \\
$\mathrm{H}_{2} \mathrm{t}(4-\mathrm{py}) \mathrm{P}$ & 416.0 & 643.0 \\
{$\left[\mathrm{H}_{4} \mathrm{t}(4-\mathrm{py}) \mathrm{P}\right]\left(\mathrm{ClO}_{4}\right)_{2}$} & 469.0 & 661.0 \\
$\Delta v\left(\mathrm{~cm}^{-1}\right)$ & -2720 & -425.3 \\
\hline
\end{tabular}

${ }^{a}$ See the footnotes of Table 2 .

of $\mathrm{H}_{2} \mathrm{t}$ (3-Mepy)P in methanol, the color changed into green, indicating the interaction of $\mathrm{H}_{2} \mathrm{t}(3-\mathrm{Mepy}) \mathrm{P}$ with the acids. The blue shift of the $\mathrm{Q}(0,0)$ band (Table 6$)$ of $\mathrm{H}_{2} \mathrm{t}(3-\mathrm{Mepy}) \mathrm{P}$ in reaction with all the acids is in line with the decreased electron donor ability of the meso substituents (vide supra).

\section{Conclusion}

In summary, the results of this study indicate the importance of resonance-type substituent effects on the shifts of the Soret as well as the $\mathrm{Q}(0,0)$ bands of $\mathrm{H}_{2} \mathrm{t}(\mathrm{py}) \mathrm{p}$ dications with weak and strong acids. The lack of correlation between the red shift of the $\mathrm{Q}(0,0)$ band of $\mathrm{H}_{2} \mathrm{t}(\mathrm{py}) \mathrm{P}$ dications with the order of $\pi$ electron donor ability of the meso substituents seems to be due to the negative effect of the shift of electron density from the pyrrolenine nitrogen atoms to the acids on the red 
TABLE 5: UV-vis spectral data for interaction of $\mathrm{H}_{2} \mathrm{t}(\mathrm{py}) \mathrm{P}$ with $\mathrm{CH}_{3} \mathrm{COOH}$ in $\mathrm{CH}_{2} \mathrm{Cl}_{2}{ }^{\mathrm{a}, \mathrm{b}}$.

\begin{tabular}{lcc}
\hline Porphyrins and the dications & $\begin{array}{c}\text { Soret band } \\
(\lambda / \mathrm{nm})\end{array}$ & $\begin{array}{c}\mathrm{Q}(0,0) \text { band } \\
(\lambda / \mathrm{nm})\end{array}$ \\
\hline $\mathrm{H}_{2} \mathrm{t}(2$-py)P & 417.0 & 642.0 \\
{$\left[\mathrm{H}_{4} \mathrm{t}(2-\right.$ pyp $\left.) \mathrm{P}\right]\left(\mathrm{CH}_{3} \mathrm{COO}\right)_{2}$} & 440.8 & 654.3 \\
$\Delta v\left(\mathrm{~cm}^{-1}\right)$ & -1294.0 & -293.0 \\
$\mathrm{H}_{2} \mathrm{t}(3-$ py)P & 418.0 & 646.4 \\
{$\left[\mathrm{H}_{4} \mathrm{t}(3-\mathrm{py}) \mathrm{P}\right]\left(\mathrm{CH}_{3} \mathrm{COO}\right)_{2}$} & 444.0 & 652.0 \\
$\Delta v\left(\mathrm{~cm}^{-1}\right)$ & -1400.9 & -132.8 \\
$\mathrm{H}_{2} \mathrm{t}(4-$ py $) \mathrm{P}$ & 416.0 & 643.0 \\
{$\left[\mathrm{H}_{4} \mathrm{t}(4-\right.$ py $\left.) \mathrm{P}\right]\left(\mathrm{CH}_{3} \mathrm{COO}\right)_{2}$} & 428.9 & 639.6 \\
$\Delta v\left(\mathrm{~cm}^{-1}\right)$ & -722.1 & 82.7 \\
\hline
\end{tabular}

${ }^{\mathrm{a}}$ See the footnotes of Table $2 .{ }^{\mathrm{b}}$ Excess amounts of acetic acid was used to complete the reaction (see Section 2.4 for details).

TABLE 6: UV-vis spectral data for protonation of $\mathrm{H}_{2} \mathrm{t}(3-\mathrm{Mepy}) \mathrm{P}$ with different acids in methanol.

\begin{tabular}{lcc}
\hline Porphyrins and the dications & $\begin{array}{c}\text { Soret band } \\
(\lambda / \mathrm{nm})\end{array}$ & $\begin{array}{c}\mathrm{Q}(0,0) \text { band } \\
(\lambda / \mathrm{nm})\end{array}$ \\
\hline $\mathrm{H}_{2} \mathrm{t}(3-$ Mepy $) \mathrm{P}$ & 419.3 & 639.7 \\
{$\left[\mathrm{H}_{4} \mathrm{t}(3-\mathrm{Mepy}) \mathrm{P}\right]\left(\mathrm{CH}_{3} \mathrm{COO}\right)_{2}$} & 437.4 & 632.8 \\
$\Delta v\left(\mathrm{~cm}^{-1}\right)^{\mathrm{a}}$ & -987.0 & 168.0 \\
{$\left[\mathrm{H}_{4} \mathrm{t}(3-\mathrm{Mepy}) \mathrm{P}\right](\mathrm{Cl})_{2}$} & 433.1 & 639.6 \\
$\Delta v\left(\mathrm{~cm}^{-1}\right)$ & -1281.0 & 2.4 \\
{$\left[\mathrm{H}_{4} \mathrm{t}(3-\mathrm{Mepy}) \mathrm{P}\right]\left(\mathrm{HSO}_{4}\right)_{2}$} & 436.3 & 632.8 \\
$\Delta v\left(\mathrm{~cm}^{-1}\right)$ & -929.0 & 168.0 \\
{$\left[\mathrm{H}_{4} \mathrm{t}(3-\mathrm{Mepy}) \mathrm{P}\right]\left(\mathrm{CF}_{3} \mathrm{COO}\right)_{2}$} & 433.5 & 631.5 \\
$\Delta v\left(\mathrm{~cm}^{-1}\right)$ & -781.0 & 201.0 \\
\hline
\end{tabular}

${ }^{a}$ Relative to the bands of $\mathrm{H}_{2} \mathrm{t}$ (3-Mepy)p.

shift of the band. Contrary to $\mathrm{H}_{2} \mathrm{t}(\mathrm{py}) \mathrm{P}$, protonation of $\mathrm{H}_{2} \mathrm{t}(3-$ Mepy)P with different acids only causes the blue shifts of the $\mathrm{Q}(0,0)$ band, indicating the significance of the $\pi$ electrondonating strength of the meso substituents on the energy of the $\mathrm{a}_{2 \mathrm{u}}$ to $\mathrm{e}_{\mathrm{g}}$ transitions. In spite of the decreased basicity of the central nitrogen atoms of $\mathrm{H}_{2} \mathrm{t}$ (3-Mepy) $\mathrm{P}$ compared to $\mathrm{H}_{2} \mathrm{t}(\mathrm{py}) \mathrm{P}$, caused by the methylation of the pyridyl groups, the former may be also protonated with $\mathrm{CH}_{3} \mathrm{COOH}$ as well as the strong acids.

\section{Acknowledgments}

The Support of this work by the Institute for Advanced Studies in Basic Sciences (IASBS) and Damghan University Research Council is acknowledged.

\section{References}

[1] A. Stone and E. B. Fleischer, "The molecular and crystal structure of porphyrin diacids," Journal of the American Chemical Society, vol. 90, no. 11, pp. 2735-2748, 1968.

[2] M. Meot-Ner and A. D. Adler, "Substituent effects in noncoplanar $\pi$ systems. ms-porphins," Journal of the American Chemical Society, vol. 97, no. 18, pp. 5107-5111, 1975.
[3] E. C. A. Ojadi, H. Linschitz, M. Gouterman et al., "Sequential protonation of meso-(p-(dimethylamino)phenyl)porphyrins: charge-transfer excited states producing hyperporphyrins," Journal of Physical Chemistry, vol. 97, no. 50, pp. 13192-13197, 1993.

[4] B. Cheng, O. Q. Munro, H. M. Marques, and W. R. Scheidt, "An analysis of porphyrin molecular flexibility-use of porphyrin diacids," Journal of the American Chemical Society, vol. 119, no. 44, pp. 10732-10742, 1997.

[5] M. O. Senge, "A conformational study of 5,10,15,20-tetraalkyl$22 \mathrm{H}^{+}, 24 \mathrm{H}^{+}$-porphyrindiium salts (dication salts)," Zeitschrift für Naturforschung-Section B, vol. 55, no. 3-4, pp. 336-344, 2000.

[6] A. Rosa, G. Ricciardi, E. J. Baerends, A. Romeo, and L. M. Scolaro, "Effects of porphyrin core saddling, meso-phenyl twisting, and counterions on the optical properties of mesotetraphenylporphyrin diacids: the $\left[\mathrm{H}_{4} \mathrm{TPP}\right](\mathrm{X})_{2}(\mathrm{X}) \mathrm{F}, \mathrm{Cl}, \mathrm{Br}$, I) series as a case study," Journal of Physical Chemistry A, vol. 107, no. 51, pp. 11468-11482, 2003.

[7] A. Rosa, G. Ricciardi, and E. J. Baerends, "Synergism of porphyrin-core saddling and twisting of meso-Aryl substituants," Journal of Physical Chemistry A, vol. 110, no. 15, pp. 5180-5190, 2006.

[8] S. Zakavi and N. G. Gharab, "Interaction of para-substituted meso-tetraphenylporphyrins and meso-tetra(n-propyl) porphyrin with weak and strong carboxylic acids: a UV-Vis spectroscopic study," Polyhedron, vol. 26, no. 12, pp. 2425-2432, 2007.

[9] S. Rayati, S. Zakavi, A. Ghaemi, and P. J. Carroll, "Core protonation of meso-tetraphenylporphyrin with tetrafluoroboric acid: unusual water-mediated hydrogen bonding of $\mathrm{H}_{4} \mathrm{tpp}^{2+}$ to the counterion," Tetrahedron Letters, vol. 49, no. 4, pp. 664-667, 2008.

[10] A. Y. Lebedev, M. A. Filatov, A. V. Cheprakov, and S. A. Vinogradov, "Effects of structural deformations on optical properties of tetrabenzoporphyrins: free-bases and Pd complexes," Journal of Physical Chemistry A, vol. 112, no. 33, pp. 7723-7733, 2008.

[11] R. E. Haddad, S. Gazeau, J. Pécaut, J. C. Marchon, C. J. Medforth, and J. A. Shelnutt, "Origin of the red shifts in the optical absorption bands of nonplanar tetraalkylporphyrins," Journal of the American Chemical Society, vol. 125, no. 5, pp. 1253-1268, 2003.

[12] S. Zakavi, M. Najafi Ragheb, and M. Rafiee, "Electrochemical Study of the dication of porphyrins with carboxylic acids: shift of the absorption bands compared to the redox potentials," Inorganic Chemistry Communications, vol. 22, pp. 48-53, 2012.

[13] S. G. DiMagno, A. K. Wertsching, and C. R. Ross, "Electronic consequences of nonplanar core conformations in electrondeficient porphyrins: the structure and spectroscopic properties of [5,10,15,20-tetrakis(heptafluoropropyl)-porphinato] cobalt(II)," Journal of the American Chemical Society, vol. 117, no. 31, pp. 8279-8280, 1995.

[14] S. Zakavi, R. Omidyan, L. Ebrahimi, and F. Heidarizadi, "Substitution effects on the UV-vis and ${ }^{1} \mathrm{H}$ NMR spectra of the dications of meso and/or $\beta$ substituted porphyrins with trifluoroacetic acid: electron-deficient porphyrins compared to the electron-rich ones," Inorganic Chemistry Communications, vol. 14, no. 11, pp. 1827-1832, 2011.

[15] K. Kalyanasundaram, "Photochemistry of water-soluble porphyrins: comparative study of isomeric tetrapyridyl- and tetrakis(N-methylpyridiniumyl)porphyrins," Inorganic Chemistry, vol. 23, no. 16, pp. 2453-2459, 1984. 
[16] I. Mayer, A. L. B. Formiga, F. M. Engelmann et al., "Study of the spectroscopic and electrochemical properties of tetraruthenated porphyrins by theoretical-experimental approach," Inorganica Chimica Acta, vol. 358, no. 9, pp. 2629-2642, 2005.

[17] S. Zakavi, A. G. Mojarrad, and S. Rayati, "Substituent effects on the catalytic activity of a series of manganese mesotetra(aryl)porphyrins: (2-, 3-, 4)-pyridyl, 4-sulfonatophenyl and 3-sulfonato-4-methoxyphenyl groups compared to phenyl and 4-methoxyphenyl ones," Journal of Molecular Catalysis A, vol. 363-364, pp. 153-158, 2012.

[18] S. Zakavi, A. G. Mojarrad, and T. M. Yazdely, "Facile purification of meso-tetra(pyridyl)porphyrins and detection of unreacted porphyrin upon metallation of meso-tetra (aryl)porphyrins," Macroheterocycles, vol. 5, no. 1, pp. 67-71, 2012.

[19] R. F. Pasternack, P. R. Huber, P. Boyd et al., "On the aggregation of meso-substituted water-soluble porphyrins," Journal of the American Chemical Society, vol. 94, no. 13, pp. 4511-4517, 1972.

[20] S. Zakavi, H. Rahiminezhad, and R. Alizadeh, "Hydrogen bond controlled adduct formation of meso-tetra(4-sulfonatophenyl) porphyrin with protic acids: a UV-vis spectroscopic study," Spectrochimica Acta-Part A, vol. 77, no. 5, pp. 994-997, 2010.

[21] Y. B. Ivanova, A. S. Semeikin, A. V. Glazunov, and N. Z. Mamardashvili, "Pyridyl-substituted porphyrins: II. Synthesis and basic properties of dipyridylporphyrins," Russian Journal of Organic Chemistry, vol. 46, no. 6, pp. 917-923, 2010.

[22] M. Gouterman, "Spectra of porphyrins," Journal of Molecular Spectroscopy, vol. 6, no. C, pp. 138-163, 1961.

[23] J. A. Joule and K. Mills, Heterocyclic Chemistryedition, chapter 7, Wiley-Blackwell, Chichester, UK, 5th edition, 2010.

[24] R. T. Morrison and R. N. Boyd, Organic Chemistry, Allyn and Bacon, Newton, Mass, USA, 5th edition, 1987. 

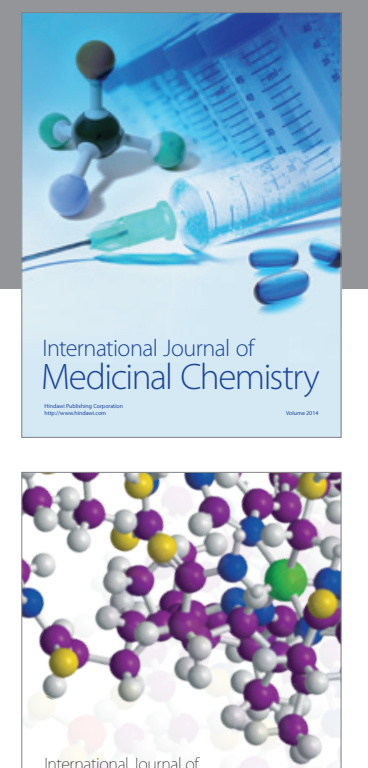

\section{Carbohydrate} Chemistry

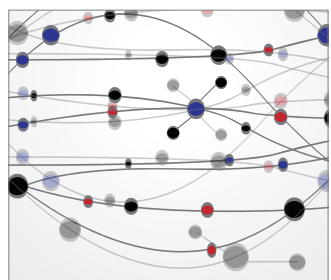

The Scientific World Journal
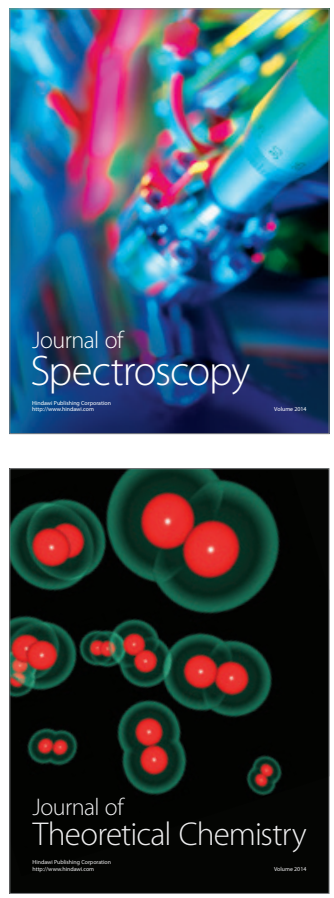
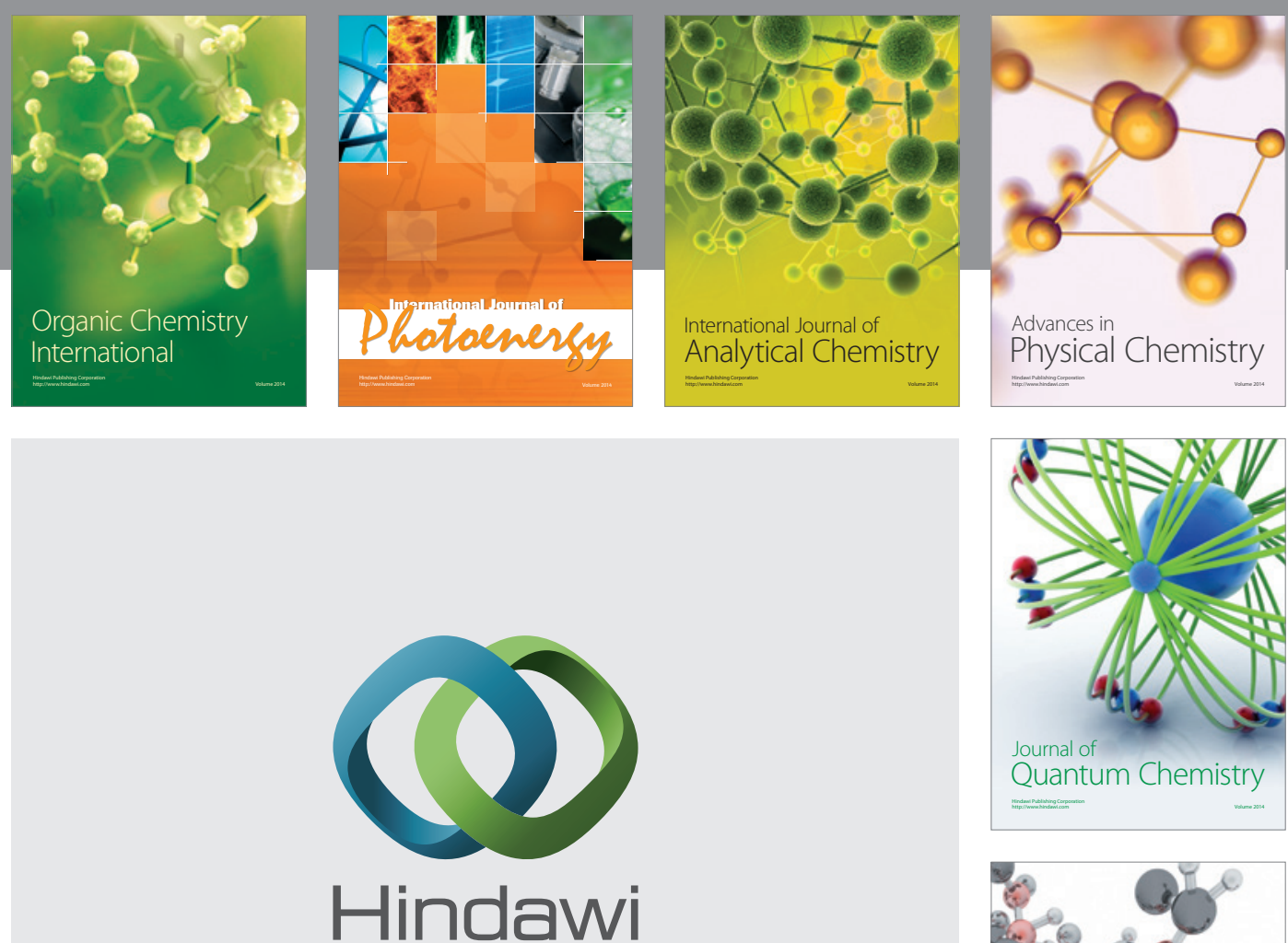

Submit your manuscripts at

http://www.hindawi.com

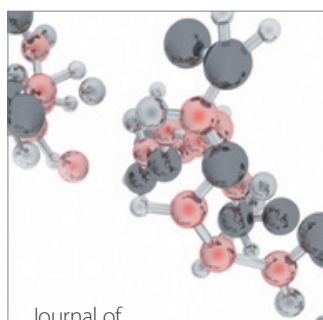

Analytical Methods

in Chemistry

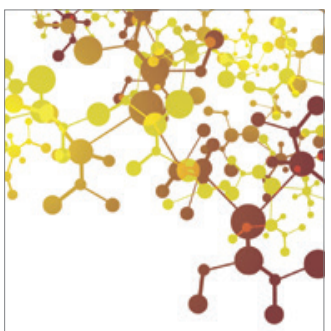

Journal of

Applied Chemistry

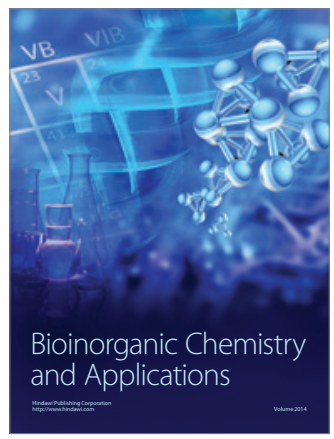

Inorganic Chemistry
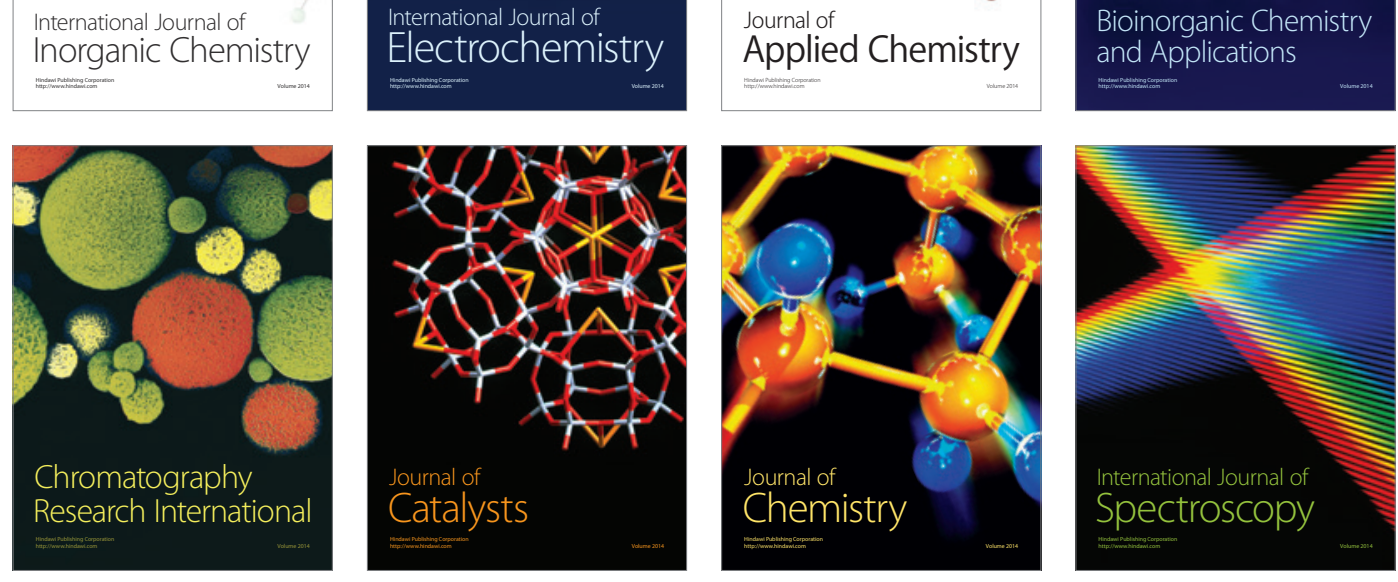